\title{
Search of Autotoxic Substances in Some Leaf Vegetables
}

\author{
Toshiki Asao*, Hiroaki Kitazawa, Takuya Ban, M. H. R. Pramanik, \\ Yoshihisa Matsui and Takashi Hosoki \\ Faculty of Life and Environmental Science, Shimane University, Kamihonjo, Shimane 690-1102
}

\begin{abstract}
Summary
The following autotoxic organic acids: lactic, benzoic, $m$-hydroxybenzoic, $p$-hydroxybenzoic, vanillic, adipic, and succinic in eight leaf vegetables, cultured hydroponically, were analyzed by GC-MS method. These substances that are adsorbed by activated charcoal are effective growth inhibits were bioassayed, using the seedlings of their origin as test materials. Strong inhibitors, such as adipic acid in parsley, lactic acid in celery, benzoic, $p$-hydroxybenzoic and succinic acid in mitsuba, vanillic acid in curly-leaf lettuce, succinic acid in edible burdock, benzoic, $m$ hydroxybenzoic and succinic acid in garland chrysanthemum, benzoic and $p$-hydroxybenzoic acid in pak-choi, benzoic, $p$-hydroxybenzoic and adipic acid in kale were found.
\end{abstract}

Key Words: autotoxicity, autotoxic substances, bioassay, leaf vegetables.

\section{Introduction}

Young (1984) reported that the root exudates of asparagus reduced the growth of asparagus seedlings. Yu and Matsui (1993) identified the phytotoxic substances that accumulated in the nutrient solution used for hydroponic culture of tomato. Furthermore, we found that the root exudates of cucumber (Asao et al., 1999b) and taro (Asao et al., 2003) were autotoxic. Thus, autotoxication would be one cause of the inhibition on the successive culture of vegetables.

Leaf vegetables, which demonstrated autotoxicity when they were cultured hydroponically, were grown with and without the addition of activated charcoal (AC) to the nutrient solutions (Asao et al., 2001). The growth and yield of pak-choi, kale, curly-leaf lettuce, head lettuce, edible burdock, garland chrysanthemum, celery, parsley and mitsuba were reduced in the absence of $\mathrm{AC}$, while growth of komatsuna, chinese cabbage, radish, takana, welsh onion, perilla and spinach were unaffected. Among the affected vegetables, the growth of parsley was most severely inhibited. However, autotoxic substances absorbed on $\mathrm{AC}$ and the degree of growth inhibition have not been clarified.

In this study, the autotoxic substances from eight leaf vegetables absorbed on $\mathrm{AC}$ were identified, and the most effective inhibitors were evaluated by bioassay.

\section{Materials and Methods}

Eight leaf vegetables, analyzed for autotoxic substances were: parsley (Petroselinum crispum $\mathrm{Nym}$.) $\mathrm{cv}$. Curl-paramount, celery (Apium graveolens L.) cv.

Received; July 8, 2003. Accepted; October 2, 2003.

* Corresponding author (E-mail: asao@life.shimane-u.ac.jp).
Mini-white, mitsuba (Cryptotaenia japonica Hassk.) cv. Yanagawa-suikou, curly-leaf lettuce (Lactuca sativus L.) cv. Banchu-red-fire, edible burdock (Arctium lappa L.) cv. Hagobo, garland chrysanthemum (Chrysanthemum coronarium L.) cv. Ohba-shingiku, pak-choi (Brassica campestris L.) cv. Choyo and kale (Brassica oleracea $\mathrm{L}$.).

\section{Identification of autotoxic substances}

The activated charcoal (AC) that was used to trap organics exuded from roots of leaf vegetables grown hydroponically (Asao et al., 2001) was desorbed three times using a mixture of methanol $(100 \mathrm{ml})$ and $0.4 \mathrm{M}$ aqueous $\mathrm{NaOH}(100 \mathrm{ml})$. Thus, each batch of $\mathrm{AC}(200$ g) was gently shaken with the alkaline methanolic solution for $12 \mathrm{hr}$ at room temperature, using an electric shaker. The three extracts were combined and filtered. And the filtrates, neutralized and concentrated to $25 \mathrm{ml}$ by a rotary vacuum evaporator at $40^{\circ} \mathrm{C}$. Organic compounds in the concentrate were extracted as described by Yu and Matsui (1993). The concentrated solution was adjusted to $\mathrm{pH} 2.0$ with $4 \mathrm{M} \mathrm{HCl}$, extracted three times with $35 \mathrm{ml}$ of refined diethyl ether (DE2), and another three times with $35 \mathrm{ml}$ of ethyl acetate (EA2). The DE2 and EA2 fractions were dried over anhydrous $\mathrm{CaSO}_{4}$ and concentrated to $5 \mathrm{ml}$ each in a rotary evaporator at $40^{\circ} \mathrm{C}$.

The DE2 and EA2 extracts were analyzed by gas chromatography coupled to a mass spectrometer (GCMS, Hitachi M-80B) before or after methylation. Fraction DE2 yielded a number of peaks on gas chromatogram, whereas EA2 yielded only a few detectable peaks. An aliquot of the concentrated DE2 fraction (1 or $2 \mathrm{ml}$ ) was diluted in $50 \mathrm{ml}$ of ether solution, treated with diazomethane, and concentrated in a rotary evaporator 
before being bubbled with an $\mathrm{N}_{2}$ stream in a water bath at $35^{\circ} \mathrm{C}$. One $-\mu 1$ of the concentrated sample was injected into a GC-MS unit coupled with a capillary column (GL Science, TC-5, $60 \mathrm{~m}$ ). Helium was used as the carrier gas at a pressure of $0.8 \mathrm{~kg} \cdot \mathrm{cm}^{-2}$. The initial column temperature was held at $100^{\circ} \mathrm{C}$ for $2 \mathrm{~min}$, then raised at $5^{\circ} \mathrm{C} \cdot \mathrm{min}^{-1}$ to a final temperature of $260^{\circ} \mathrm{C}$ with isotherm for $10 \mathrm{~min}$. The injector temperature was held at $270^{\circ} \mathrm{C}$. The ionization voltage and temperature in the electron impact (EI) mode were $70 \mathrm{eV}$ and $250^{\circ} \mathrm{C}$, respectively.

\section{Bioassay with vegetable seedlings}

The autotoxic effects by the identified compounds were evaluated by using seedlings of plants from which they originated. Aqueous solutions of the identified acids at concentrations of 0 (control), 50, 100, 200 and $400 \mu \mathrm{M}$ were prepared with a $75 \%$ Enshi nutrient solution (EC $2.0 \mathrm{dS} \cdot \mathrm{m}^{-1}$ ) (Pramanik et al., 2000). The test solutions were added as per treatment to $400 \mathrm{ml}$ conical flasks, which were wrapped with black polyethylene to avoid direct light to the roots (Asao et al., 1999a, b). One seedling was transplanted to each flask with urethane foam as a support. Plants were placed in a growth chamber at $25^{\circ} \mathrm{C}$ and a 16 -hr photoperiod under a fluorescent light having a light intensity of $74-81$ $\mu \mathrm{mol} \cdot \mathrm{m}^{-2} \cdot \mathrm{s}^{-1}$. To minimize the effect of microbial degradation in the bioassay (Sundin et al., 1990), the test solutions were renewed at 3-or 4-day intervals. The seedlings were grown for two weeks and the dry weights of shoots were recorded. Each treatment was replicated 10 times.

\section{Results and Discussion}

Analyses of root exudates released from AC by GCMS after methylation revealed the presence of the following acids: lactic, benzoic, $p$-hydroxybenzoic, adipic and succinic in parsley, edible burdock, and kale;

Table 1. Effects of identified compounds at different concentrations on the dry weight $(\mathrm{mg})$ of shoot in eight leaf vegetables.

\begin{tabular}{|c|c|c|c|c|c|c|c|c|c|}
\hline \multicolumn{2}{|c|}{$\begin{array}{c}\text { Compounds }^{z} \\
\text { (Concentration, } \mu \mathrm{M} \text { ) }\end{array}$} & \multirow{2}{*}{$\frac{\text { Parsley }}{29 a^{x}}$} & \multirow{2}{*}{$\begin{array}{c}\text { Celery } \\
23 a\end{array}$} & \multirow{2}{*}{$\begin{array}{c}\text { Mitsuba } \\
34 a\end{array}$} & \multirow{2}{*}{$\begin{array}{c}\begin{array}{c}\text { Curlyleaf } \\
\text { lettuce }\end{array} \\
54 a\end{array}$} & \multirow{2}{*}{$\begin{array}{c}\begin{array}{c}\text { Edible } \\
\text { burdock }\end{array} \\
142 \mathrm{a}\end{array}$} & \multirow{2}{*}{$\begin{array}{l}\text { Garland } \\
\text { chrysan- } \\
\text { themum }\end{array}$} & \multirow{2}{*}{$\begin{array}{c}\text { Pakchoi } \\
71 \mathrm{a}\end{array}$} & \multirow{2}{*}{$\begin{array}{c}\text { Kale } \\
80 a\end{array}$} \\
\hline Control (No compound) ${ }^{y}$ & 0 & & & & & & & & \\
\hline \multirow[t]{4}{*}{ Lactic acid } & 50 & $22 \mathrm{a}$ & $21 \mathrm{a}$ & $35 \mathrm{a}$ & $43 \mathrm{a}$ & $150 \mathrm{a}$ & $17 \mathrm{a}$ & $69 a$ & $79 a$ \\
\hline & 100 & $22 \mathrm{a}$ & $19 \mathrm{a}$ & $35 \mathrm{a}$ & $43 \mathrm{a}$ & $131 \mathrm{a}$ & $18 \mathrm{a}$ & $71 \mathrm{a}$ & $63 b$ \\
\hline & 200 & $22 \mathrm{a}$ & $16 \mathrm{~b}$ & $36 \mathrm{a}$ & $47 a$ & $126 a$ & $19 \mathrm{a}$ & $44 b$ & $63 b$ \\
\hline & 400 & $16 b$ & $16 \mathrm{~b}$ & $36 a$ & $50 \mathrm{a}$ & $110 \mathrm{~b}$ & $19 \mathrm{a}$ & $41 b$ & $48 \mathrm{c}$ \\
\hline \multirow[t]{4}{*}{ Benzoic acid } & 50 & $22 \mathrm{a}$ & $18 \mathrm{a}$ & $32 a$ & $58 \mathrm{a}$ & $124 \mathrm{a}$ & $11 b$ & $61 \mathrm{a}$ & $64 \mathrm{~b}$ \\
\hline & 100 & $16 \mathrm{~b}$ & $18 \mathrm{a}$ & $32 \mathrm{a}$ & $64 a$ & $121 \mathrm{a}$ & $12 b$ & $39 b$ & $52 \mathrm{c}$ \\
\hline & 200 & $16 \mathrm{~b}$ & $17 \mathrm{a}$ & $28 \mathrm{~b}$ & $53 a$ & $82 b$ & $13 b$ & $35 b$ & $45 c$ \\
\hline & 400 & $12 \mathrm{c}$ & $19 \mathrm{a}$ & $24 c$ & $40 \mathrm{~b}$ & $72 b$ & $12 b$ & $30 \mathrm{c}$ & $35 c$ \\
\hline$m$-hydroxy - & 50 & $-w$ & - & $37 a$ & - & - & $13 b$ & - & - \\
\hline \multirow[t]{3}{*}{ benzoic acid } & 100 & - & - & $37 a$ & - & - & $13 b$ & - & - \\
\hline & 200 & - & - & $34 a$ & - & - & $11 \mathrm{c}$ & - & - \\
\hline & 400 & - & - & $23 b$ & - & - & $12 \mathrm{c}$ & - & - \\
\hline \multirow{4}{*}{$\begin{array}{l}p \text {-hydroxy }- \\
\text { benzoic acid }\end{array}$} & 50 & $22 a$ & $20 \mathrm{a}$ & $33 a$ & $63 a$ & $116 a$ & $17 \mathrm{a}$ & $91 \mathrm{a}$ & $59 b$ \\
\hline & 100 & $19 b$ & $24 a$ & $34 \mathrm{a}$ & $55 \mathrm{a}$ & $106 a$ & $18 \mathrm{a}$ & $49 b$ & $52 \mathrm{~b}$ \\
\hline & 200 & $18 \mathrm{~b}$ & $17 \mathrm{a}$ & $26 \mathrm{~b}$ & $52 \mathrm{a}$ & $103 \mathrm{~b}$ & $16 \mathrm{~b}$ & $34 c$ & $46 c$ \\
\hline & 400 & $13 \mathrm{c}$ & $17 \mathrm{a}$ & $23 c$ & $33 b$ & $90 \mathrm{~b}$ & $12 \mathrm{c}$ & $29 c$ & $34 c$ \\
\hline \multirow[t]{4}{*}{ Vanillic acid } & 50 & - & - & - & $32 b$ & - & $16 a$ & - & - \\
\hline & 100 & - & - & - & $33 b$ & - & $15 \mathrm{a}$ & - & - \\
\hline & 200 & - & - & - & $33 b$ & - & $14 b$ & - & - \\
\hline & 400 & - & - & - & $33 b$ & - & $11 \mathrm{c}$ & - & - \\
\hline \multirow[t]{4}{*}{ Adipic acid } & 50 & $18 \mathrm{~b}$ & - & $37 \mathrm{a}$ & $58 \mathrm{a}$ & $135 \mathrm{a}$ & $17 \mathrm{a}$ & - & $56 \mathrm{~b}$ \\
\hline & 100 & $17 \mathrm{~b}$ & - & $36 \mathrm{a}$ & $58 \mathrm{a}$ & $130 \mathrm{a}$ & $17 \mathrm{a}$ & - & $66 \mathrm{~b}$ \\
\hline & 200 & $17 \mathrm{~b}$ & - & $36 a$ & $52 \mathrm{a}$ & $130 \mathrm{a}$ & $18 \mathrm{a}$ & - & $46 c$ \\
\hline & 400 & $13 c$ & - & $36 a$ & $46 a$ & $110 \mathrm{a}$ & $16 \mathrm{a}$ & - & $37 \mathrm{c}$ \\
\hline \multirow[t]{4}{*}{ Succinic acid } & 50 & $22 \mathrm{a}$ & - & $33 a$ & $50 a$ & $116 \mathrm{a}$ & $14 b$ & - & $69 a$ \\
\hline & 100 & $23 a$ & - & $31 \mathrm{a}$ & $51 \mathrm{a}$ & $94 b$ & $13 b$ & - & $66 a$ \\
\hline & 200 & $18 \mathrm{~b}$ & - & $28 \mathrm{~b}$ & $43 b$ & $85 b$ & $11 \mathrm{c}$ & - & $51 b$ \\
\hline & 400 & $16 \mathrm{~b}$ & - & $21 \mathrm{c}$ & $41 b$ & $83 \mathrm{~b}$ & $10 \mathrm{c}$ & - & $37 \mathrm{c}$ \\
\hline
\end{tabular}

${ }^{z}$ Compounds identified in the root exudates (adsorbed on the activated charcoal) of eight leaf vegetables grown hydroponically.

${ }^{\mathrm{y}}$ Control of all compounds.

${ }^{x}$ Mean separation within columns in each compound by Tukey's test at $5 \%$ level.

${ }^{w}$ Not detected. 
lactic, benzoic, and $p$-hydroxybenzoic in celery and pakchoi. Also lactic, benzoic, $m$-hydroxybenzoic, $p$ hydroxybenzoic, adipic, and succinic were present in mitsuba; lactic, benzoic, $p$-hydroxybenzoic, vanillic, adipic, and succinic were detected in lettuce; and lactic, benzoic, $m$-hydroxybenzoic, $p$-hydroxybenzoic, vanillic, adipic, and succinic were found in garland chrysanthemum (Table 1).

Bioassays of the identified compounds in the root exudates of each vegetable revealed that adipic acid induced the retardation of the dry weight (DW) of parsley shoots even at $50 \mu \mathrm{M}$ (Table 1). Lactic acid in celery at $200 \mu \mathrm{M}$ reduced DW to $70 \%$ of control values, whereas that benzoic, $p$-hydroxybenzoic and succinic acid in mitsuba at $200 \mu \mathrm{M}$ decreased DW accumulation to 82,76 and $82 \%$ of control values, respectively. Vanillic acid in curly-leaf lettuce and benzoic, $m$ hydroxybenzoic and succinic acids in garland chrysanthemum even at $50 \mu \mathrm{M}$ reduced DW to $59,65,76$ and $82 \%$ of control, respectively; likewise, succinic acid at $100 \mu \mathrm{M}$ decreased DW in edible burdock to $66 \%$ of control. Benzoic and $p$-hydroxybenzoic acids in pakchoi at $100 \mu \mathrm{M}$, and benzoic, $p$-hydroxybenzoic and adipic acids in kale at $50 \mu \mathrm{M}$ reduced DW to 55, 69, 80, 74 and $70 \%$ of control values, respectively.

In summary, adipic acid was the strongest inhibitor in parsley and lactic acid in celery. Benzoic, $p$-hydroxybenzoic and succinic acids induced strong inhibition in mitsuba. Vanillic acid caused the most severe growth inhibition in curly-leaf lettuce. Succinic acid in edible burdock, and benzoic, $m$-hydroxybenzoic and succinic acids in garland chrysanthemum induced strong inhibition. Benzoic and $p$-hydroxybenzoic acids strongly inhibited the growth of pak-choi while benzoic, $p$ hydroxybenzoic and adipic acids inhibited the growth of kale. Benzoic acid was the strongest overall inhibitor for all leaf vegetables among the substances tested. These results confirm that some unidentified compounds inhibited growth of leaf vegetables in hydroponic culture (Asao et al., 2001). In our experiments, some of these compounds absorbed on AC were identified as aromatic and aliphatic acids which have been cited as allelochemicals (Rice, 1984).

\section{Literature cited}

Asao, T., M. H. R. Pramanik, K. Tomita, Y. Ohba, K. Ohta, T. Hosoki and Y. Matsui. 1999a. Identification and growth effects of compounds adsorbed on activated charcoal from hydroponic nutrient solutions of cucumber. Allelopathy J. 6: 243-250.

Asao, T., M. H. R. Pramanik, K. Tomita, Y. Ohba, K. Ohta, T. Hosoki and Y. Matsui. 1999b. Influences of pheno- lics isolated from the nutrient solution nourishing growing cucumber (Cucumis sativus L.) plants on fruit yield. J. Japan. Soc. Hort. Sci. 68: 847-853 (In Japanese with English summary).

Asao, T., K. Taniguchi, K. Tomita and T. Hosoki. 2001. Species differences in the susceptibility to autotoxicity among leaf vegetables grown in hydroponics. J. Japan. Soc. Hort. Sci. 70: 519-521 (In Japanese with English summary).

Asao, T., K. Hasegawa, Y. Sueda, K. Tomita, K. Taniguchi, T. Hosoki, M. H. R. Pramanik and Y. Matsui. 2003. Autotoxicity of root exudates from taro. Scientia Hortic. 97: 389-396.

Pramanik, M. H. R., M. Nagai, T. Asao and Y. Matsui. 2000. Effects of temperature and photoperiod on phytotoxic root exudates of cucumber (Cucumis sativus) in hydoroponic culture. J. Chem. Ecol. 26: 1953-1967.

Rice, E. L. 1984. Allelopathy. p. 422. Academic Press, Orlando.

Sundin, P., A. Valeur, S. Olsson and G. Odham. 1990. Interactions between bacteria-feeding nematodes and bacteria in the rape rhizosphere: Effects on root exudation and distribution of bacteria. FEMS Microbiology Ecology. 73: 13-22.

Young, C. C. 1984. Autotoxication in root exudates of Asparagus officinalis L. Plant and Soil. 32: 247-253.

Yu, J. Q. and Y. Matsui. 1993. Extraction and identification of the phytotoxic substances accumulated in the nutrient solution for the hydroponic culture of tomato. Soil. Sci. Plant Nutr. 39: 691-700.

\section{葉菜類の自家中毒物質の探索}

浅尾俊樹・北澤裕明・伴 环也・M. H. R. Pramanik • 松井佳久・細木高志

島根大学生物資源科学部 690-1102 松江市上本庄町

摘 要

8 種の葉菜類の自家中毒物質を探索するために水耕葉菜類 に用いた活性炭に吸着された物質を GC-MS 法で分析した。 その物質は乳酸, 安息香酸, $m$-七ドロキシ安息香酸， $p$-七 ドロキシ安息香酸,バニリン酸,アジピン酸およびコ八ク酸 であった．同定された物質の中で, 顕著に生育抑制を引き起 こす物質を探るため各葉菜類の苗を使ったバイオアッセイを 行ったそその結果，パセリではアジピン酸，セロリでは乳酸， ミツバでは安息香酸，p-ヒドロキシ安息香酸およびコハク 酸、レタスではバニリン酸, 葉ゴボウではコハク酸, シュン ギクでは安息香酸， $m$-ヒドロキシ安息香酸およびコ八ク酸， チンゲンサイでは安息香酸および $p$-ヒドロキシ安息香酸, ケールでは安息香酸， $p$-ヒドロキシ安息香酸およびアジピ ン酸が生育抑制を顕著に引き起こす物質として認められた。 